ISSN 0103-5150

Fisioter. Mov., Curitiba, v. 30, n. 3, p. 453-461, Jul./Sep. 2017

Licenciado sob uma Licença Creative Commons

DOI: http://dx.doi.org/10.1590/1980-5918.030.003.A003

\title{
Relationship between head posture and lumbar curve in a sitting position: a biomechanical study
}

\author{
Relação entre a postura da cabeça e a \\ curvatura lombar na posição sentada: \\ um estudo biomecânico
}

Rozilene Maria Cota Aroeira, Renata Maria Moreira Moraes Furlan, Antônio Eustáquio de Melo Pertence, Estevam Barbosa de Las Casas, Marcelo Greco*

Escola de Engenharia de Estruturas da Universidade Federal de Minas Gerais (UFMG), Belo Horizonte, MG, Brazil

\begin{abstract}
Introduction: The sitting position routinely used for a wide variety of tasks increases the potential of developing forward head posture, which can seriously compromise the health of different systems in the human body. Objective: A static equilibrium analysis was conducted, comparing the position of the head with the lumbar curve in three different sitting positions. Methods: The approximate force and flexion moment of the head extensor muscles in static equilibrium was calculated in each of the following positions: (A) without a backrest; (B) using a backrest with a $100^{\circ}$ tilt angle; (C) using a $100^{\circ}$ tilted backrest associated with a cylindrical lumbar support cushion at the level of the L3 vertebra. Results: The C7-tragus angles were $43^{\circ}$, $50^{\circ}$ and $52^{\circ}$; Frankfort horizontal plane (FH) angles were $5^{\circ}, 9^{\circ}$ and $9^{\circ}$; force of the head extensor muscles was $53.0 \mathrm{~N}, 59.7 \mathrm{~N}$ and $43.5 \mathrm{~N}$ and flexion moments were $2.60 \mathrm{Nm}, 2.05 \mathrm{Nm}$ and $1.78 \mathrm{Nm}$, in positions $\mathrm{A}, \mathrm{B}$ and $\mathrm{C}$, respectively. Conclusion: The results revealed that the sitting position using a $100^{\circ}$ tilted backrest and lumbar support with the smallest L3-tragus horizontal distance required less effort by the head and neck extensor muscles to retain the head in equilibrium. This study demonstrated the need to preserve the
\end{abstract}

RMCA: PhD, e-mail: rozecota@hotmail.com RMMMF: PhD, e-mail: renatamfurlan@yahoo.com.br AEMP: PhD, e-mail: pertence@demec.ufmg.br EBLC: PhD, e-mail: estevam.lascasas@gmail.com MG: PhD, e-mail: mgreco@dees.ufmg.br 
physiology of the lumbar spine, characterized by the position of the L3 vertebra, in order to ensure good head position.

Keywords: Posture. Spine. Biomechanics. Photogrammetry. Employee Health

\section{Resumo}

Introdução: A postura do indivíduo sentado, utilizada rotineiramente na execução de grande variedade de tarefas, constitui-se num potencial aumentado para o desenvolvimento da postura de projeção da cabeça, a qual pode ocasionar sérios comprometimentos à saúde de vários sistemas no corpo humano. Objetivo: Um estudo do equilíbrio estático foi realizado, relacionando a posição da cabeça com a curvatura da coluna lombar em três diferentes posturas do indivíduo sentado. Métodos: Foi realizado o cálculo do valor aproximado de força e momento fletor dos músculos extensores da cabeça na manutenção do equilíbrio estático em cada uma das seguintes posturas: (A) sem uso de encosto para as costas; (B) com uso de encosto de $100^{\circ}$ de inclinação; (C) com uso de encosto de $100^{\circ}$ associado a um suporte lombar cilíndrico em nível da vértebra L3. Resultados: Os ângulos tragus-C7 foram $43^{\circ}, 50^{\circ}$ e 52 ; os ângulos de Frankfort foram $5^{\circ}, 9^{\circ}$ e $9^{\circ}$; as forças musculares extensoras da cabeça foram 53,0N, 59,7N e 43,5N e os momentos fletores foram 2,60N.m, 2,05N.m e 1,78N.m, nas posturas $A$, $B$ e $C$, respectivamente. Conclusão: Os resultados revelaram que a postura sentada com encosto inclinado a $100^{\circ}$ e calço lombar, onde houve a menor distância horizontal tragus-L3, apresentou menor esforço para a musculatura cervical extensora na manutenção do equilíbrio da cabeça. Este estudo demonstrou a necessidade da preservação do eixo lombar fisiológico, caracterizado pelo posicionamento da vértebra L3, para garantir o bom posicionamento da cabeça.

Palavras-chave: Postura. Coluna vertebral. Biomecânica. Fotogrametria. Saúde do Trabalhador.

\section{Introduction}

The physiology and sound functioning of the human body are closely related to body posture, which affects and governs everything from breathing to hormone production (1). Correct posture is considered an important indicator of musculoskeletal health, with disorders of this system primarily caused by mechanical stress $(2,3)$. The sitting position routinely used for a wide variety of tasks increases the potential of developing forward head posture, considered abnormal and frequently observed in medical practice (4). According to Marques et al. (5), sitting for more than four hours may pose a risk to the musculoskeletal system.

Forward head posture has been associated with chronic musculoskeletal and functional disorders in the craniofacial region, neck and shoulders $(6,7,8$, $9)$. The annual prevalence of neck pain varies in different countries, from $27.1 \%$ to $47.8 \%$ (10). However, prevalence can increase significantly as a result of specific work-related tasks, such as in dentistry and among professionals who use visual display units in their work routines $(11,12,13)$. Gazzola et al. (14) found a high prevalence (98.6\%) of musculoskeletal disorders in 71 young dentists, with the most affected regions being the cervical spine (77.5\%), lumbar spine $(73.3 \%)$ and shoulders (69\%). In a study by Kang et al. (15), a group of individuals who remained seated at a computer for six or more hours a day for over ten years exhibited forward head posture, a forward shift in the body's center of gravity, and reduced balance and postural control when compared to a control group. In a literature review, Côté et al. (10) reported that neck pain is a significant health problem among employees. Every year, at least 5\% of the population is expected to develop frequent or persistent neck disorders and there is evidence that head posture is a risk factor associated with these conditions. Zandi et al. (16) highly recommend head posture assessment for patients with head and neck pain for the purpose of diagnosis, planning, treatment strategy and monitoring.

The position of the head in relation to the cervical spine (neck) has been measured as the angle between a line drawn through the tragus (outer ear) 
and a horizontal line through the spinous process of the C7 vertebra (17). Studies have shown that this angle, measured in adults, is between 49 and $55^{\circ}(18,19,20)$. The head-neck ratio should be assessed along the sagittal plane. According to Nordin \& Frankel (21), the ratio is evaluated when the subject is in a relaxed standing position, where the line of gravity passes immediately in front of the outer ear and descends ventrally to the lumbar spine. This line moves further forward in a relaxed sitting position with no back support. In this condition, the center of mass (CM) moves toward the ischial tuberosity, the pelvis is tilted and lumbar curvature is neutral or inverted. This movement creates a longer moment arm for the force exerted by the weight of the upper portion of the body. When sitting upright the CM coincides with the ischial tuberosity, the pelvis is in a neutral position and the moment arm is shorter, but still slightly longer than that observed in a relaxed standing position (22).

The aim of this study was to: i. compare the position of the head to lumbar curvature in three different sitting positions, using posture analysis by computerized photogrammetry; ii. measure the approximate force and flexion moment of the head extensor muscles in the three positions at static equilibrium.

\section{Methods}

Photograph collection and angle measurement by computerized photogrammetry

An 18-year-old female volunteer with a weight of $53 \mathrm{~kg}$ and height of $1.65 \mathrm{~m}$ was photographed from the left sagittal plane after markers were placed on anatomical reference points. A $13 \mathrm{~mm}$-wide circular white marker was placed on the left tragus (at the entrance to the external auditory canal) and anatomical tracking markers measuring $45 \mathrm{~mm}$ by $18.79 \emptyset$ were positioned on the spinous processes of vertebrae $\mathrm{C} 7$ to L5 (23). The volunteer was photographed in three different sitting positions: (A) without a backrest; (B) using a backrest with a $100^{\circ}$ tilt angle; (C) using a $100^{\circ}$ tilted backrest associated with a cylindrical lumbar support cushion at the level of the L3 vertebra, after approval by the Research Ethics Committee (COEP/UFMG under protocol number ETIC 579/07.

Anthropometric data were also obtained, including: head diameters, neck perimeter, combined length of the head and neck, weight and height. Photographs were taken using a Sony Cyber-Shot 4.1 megapixel camera mounted on a tripod, a chair without a backrest and one with a $100^{\circ}$ tilted backrest, as well as a Mckenzie $^{\circledR}$ lumbar support cushion. In order to ensure the images could be compared, the camera and tripod were positioned at right angles to the volunteer at a focal length of $2.0 \mathrm{~m}$, respecting the 1.2 to $2.4 \mathrm{~m}$ interval recommended by Ricieri (24) and using minimum zoom.

\section{Computerized Photogrammetry}

After photograph collection the images were submitted to angular kinematics via computerized photogrammetry, using Corel Draw $13^{\circledR}$ software. Angles were measured after identifying the center of anatomical markers on the computer screen using the zoom feature, which was standardized for the entire photographic analysis process in order to prevent measurement errors. The C7-tragus angle was measured according to the protocol recommended by Braun \& Amundson (17), analyzing the position of the head in relation to the body. This cervical angle is highly reliable in assessing forward head posture (25). Deviation of the thoracic and lumbar segments related to the L3 vertebra was also assessed. The vertical direction of the gaze was analyzed by measuring the angle of the Frankfort plane, which passes through the tragus and the outer edge of the eye socket. The angle is positive when the lower edge of the eye socket is higher than the tragus (26).

\section{Photo Interpretation}

This involves interpreting photogrammetric measurements in order to determine their meaning within the field of knowledge related to the object of this study.

\section{Mathematical Analysis of the Data}

Head and neck measurements

First, the dimensions of the volunteer's head were measured: $e=15 \mathrm{~cm}, f=20 \mathrm{~cm}$ and $g=22 \mathrm{~cm}$, where $e, f$ and $g$ are the axes of the ellipse that is an approximate 
representation of the head, with $f$ representing the vertical axis. Neck dimensions and head-neck length were: neck perimeter $s=31 \mathrm{~cm}$ and distance from the base of the neck to the top of the head $H=25 \mathrm{~cm}$, respectively. The following simplifying assumptions were made: the geometric center (centroid) is equal to the center of gravity (CG); ii- the head-neck assembly used in the calculation obtained by simplification of the lateral areas of the ellipse and cylinder (27). Based on these measurements, the areas of the ellipse (Equation 1) and rectangle (Equation 2) were calculated, for subsequent determination of the CG (Equation 3). In other words, it is assumed that the geometric center was in approximately the same position as the center of gravity. This simplifying assumption is valid due to the approximate symmetry of the head-neck assembly, as shown in Figure 1.

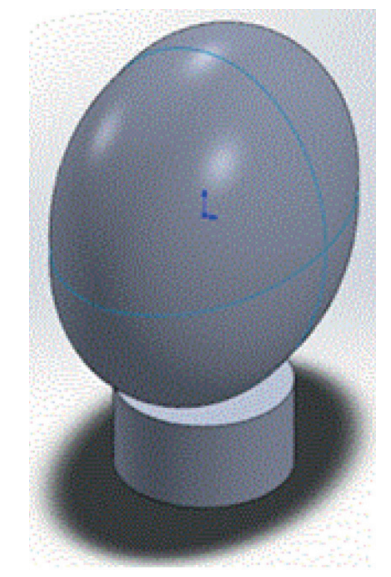

Figure 1 - Head-neck assembly.

The CG of the head-neck assembly was calculated as follows:

Calculation of the area of the ellipse:

$\mathrm{A}_{\text {ellipse }}=\pi \cdot f \cdot g$

Calculation of the lateral area of the cylinder:

$\mathrm{A}_{\text {cylinder }}=2 \cdot r \cdot h$

Where $r$ and $h$ are, respectively, the radius of the cylinder and the height of the rectangle, which are an approximate representation of the neck.

Calculation of the CG of the assembly:

$$
\overline{\mathrm{y}}=\sum_{\mathrm{i}=1}^{2} \frac{\overline{\mathrm{y}}_{\mathrm{i}} \cdot \mathrm{A}_{\mathrm{i}}}{\sum \mathrm{A}_{\mathrm{i}}}
$$

The CG of the head and neck assembly of the volunteer was $11.56 \mathrm{~cm}$ from the apex of the head in the $Y$ direction; $11 \mathrm{~cm}$ from the rearmost point of the head in the $\mathrm{Z}$ direction and $7.5 \mathrm{~cm}$ from either ear in the $\mathrm{x}$ direction.

\section{Results}

Measurement by computerized photogrammetry

Sitting position without a backrest

The C7-tragus angle with the horizontal line, measured by computerized photogrammetry, was $43^{\circ}$ and the Frankfort plane angle was $5^{\circ}$. In this position, posterior projection of L3 and forward head posture were observed, prompting an increase in the distance between the tragus and the spinous process of $\mathrm{L} 3$ ( $\mathrm{Tr}$ L3), whose value on the virtual scale was $15.53 \mathrm{~mm}$. As a result, changes occurred in the physiological curvature of the spine, such as: correction of cervical lordosis, increased thoracic kyphosis, and reversal of lordosis, as shown in Figure 2A.

Sitting position in a chair with a $100^{\circ}$ tilted backrest

The forward head angle was $50^{\circ}$ and the angle of the Frankfort plan was $9^{\circ}$. In this position there was less posterior projection of L3 compared to the thoracic segment and a significant reduction in the horizontal Tr-L3 distance, measured at $9.05 \mathrm{~mm}$ (Figure 2B).

\section{Sitting position in a chair with a $100^{\circ}$ tilted} backrest and lumbar support at L3

The forward head angle was $52^{\circ}$ and the angle of the Frankfort plan was $9^{\circ}$. This position exhibited the smallest horizontal Tr-L3 distance $(8.41 \mathrm{~mm})$ of all three postures. In addition, alignment of the posterior thoracic curve and hip was observed (Figure 2C). 


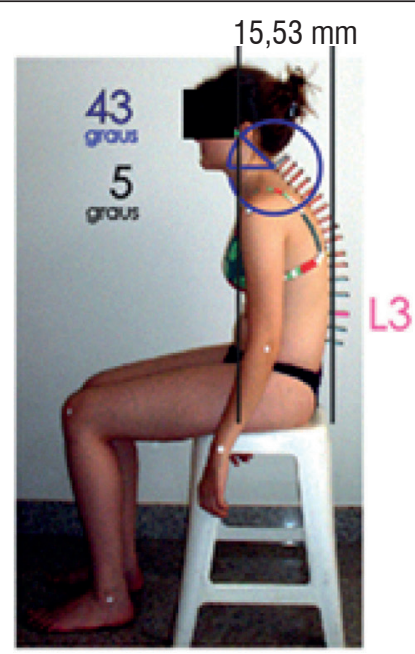

(A) sem encosto

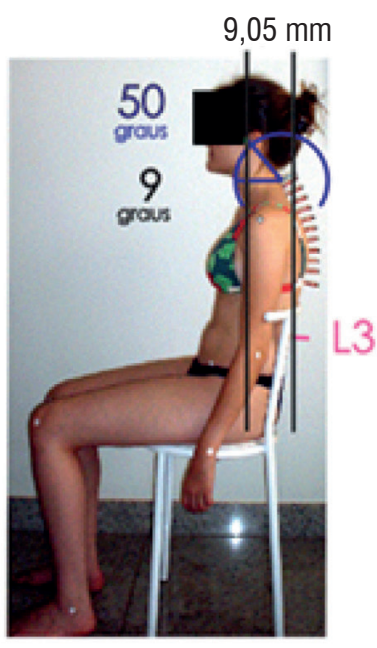

(B) com encosto e sem calço

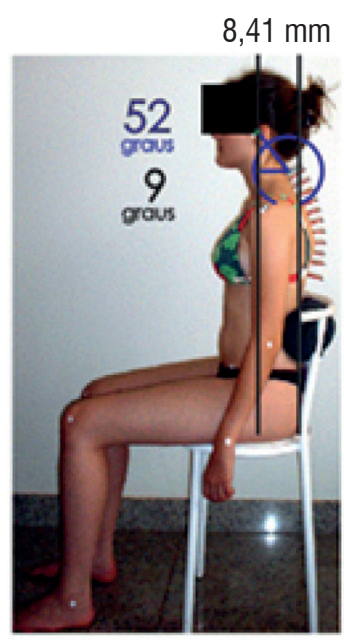

(B) com calço em L3

Figure 2 - Sitting position of the volunteer: (A) in a chair with no backrest, C7-tragus angle of $43^{\circ}$, Frankfort plane $5^{\circ}$ and Tr-L3 distance of $15.53 \mathrm{~mm}$;(B) with a $100^{\circ}$ tilted backrest, C7-tragus angle of $50^{\circ}$, Frankfort plane $9^{\circ}$ and Tr-L3 distance of $9.05 \mathrm{~mm}$ and (C) with a $100^{\circ}$ tilted backrest and lumbar support cushion at the level of vertebra L3, C7-tragus angle of $52^{\circ}$, Frankfort plane $9^{\circ}$ and $\mathrm{Tr}-\mathrm{L} 3$ distance of $8.41 \mathrm{~mm}$.

After conversion into real values, the Tr-L3 distances were: (A) Tr-L3 $=18.88 \mathrm{~cm}$; (B) $\mathrm{Tr}-\mathrm{L} 3=11.0 \mathrm{~cm}$ and (C) Tr-L3 = $10.23 \mathrm{~cm}$.

\section{Calculation of the force and flexion moment of head extensor muscles}

The head extensor muscles and C7-T1 joint were identified by palpation of surface anatomy. The lines representing the force vectors were drawn based on these references. The mass of the head was considered to be $8 \%$ of body weight $(53 \mathrm{~kg}$ ), that is, approximately $4 \mathrm{~kg}(28)$. The magnitude of the resulting muscle force exerted by the head extensor muscles was denominated FM and the reaction force on the C7-T1 joint, FJ (Figure 3).

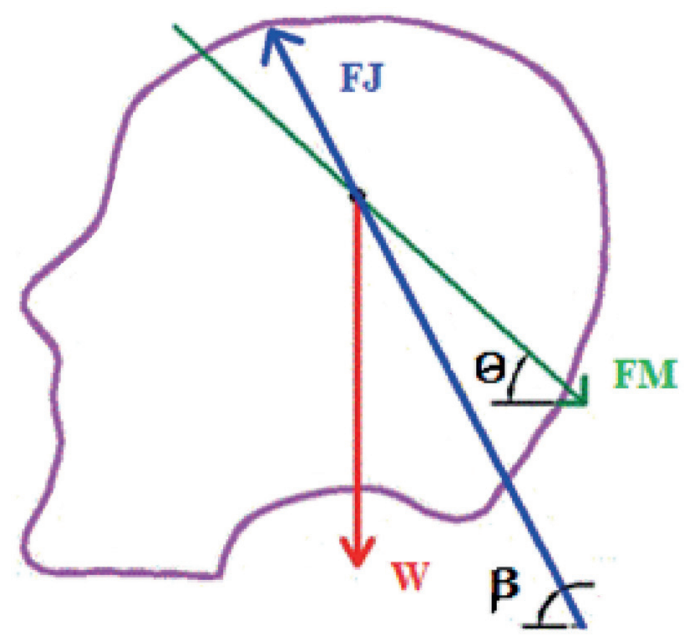

Figure 3 - FM represents the magnitude of the resulting muscle force exerted by the head extensor muscles, $\theta$ depicts the angle between the FM vector and the horizontal line, FJ the reaction force on the C7-TI, $\beta$ the angle between the FJ vector and the horizontal line and W the weight of the head. Adapted from Nordin \& Frankel (1989). 
The angles between FM and FJ and the horizontal line were obtained by computerized photogrammetry, as shown in Figure 4. Based on equilibrium equations, since the relative weights FM and FJ are competing forces, the force required by the head extensor muscles to support the head in the different positions studied was calculated (Equations 4 to 7).

$$
\begin{aligned}
& \left|\mathrm{FM}_{\mathrm{X}}\right|=\mathrm{FM} \cdot \cos (\theta) \\
& \left|\mathrm{FM}_{\mathrm{Y}}\right|=\mathrm{FM} \cdot \operatorname{sen}(\theta) \\
& \left|\mathrm{FJ}_{\mathrm{X}}\right|=\mathrm{FJ} \cdot \cos (\beta) \\
& \left|\mathrm{FJ}_{\mathrm{Y}}\right|=\mathrm{FJ} \cdot \operatorname{sen}(\beta)
\end{aligned}
$$

The static equilibrium equations using CG as reference provided equations (8) and (9):

$$
\begin{aligned}
& |\mathrm{FM}|=\frac{39 \cdot 24}{\tan (\beta) \cdot \cos (\theta)-\operatorname{sen}(\theta)} \\
& |\mathrm{FJ}|=\frac{\cos (\theta)}{\cos (\beta)}|\mathrm{FM}|
\end{aligned}
$$

The flexion moment was calculated using linear interpolation to obtain the real distance of the C7-y axis measurement, expressed in millimeters in the measurement software (Figure 4).

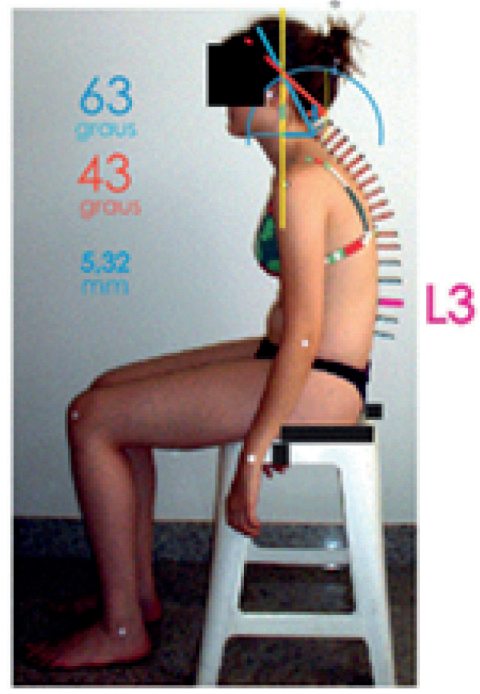

(A) sem encosto

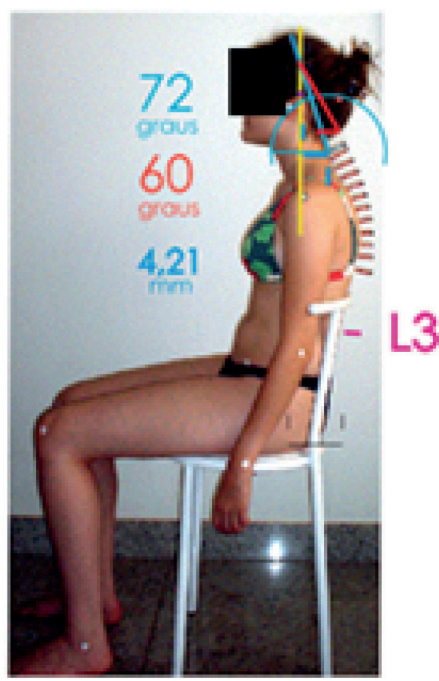

(B) com encosto e sem calço

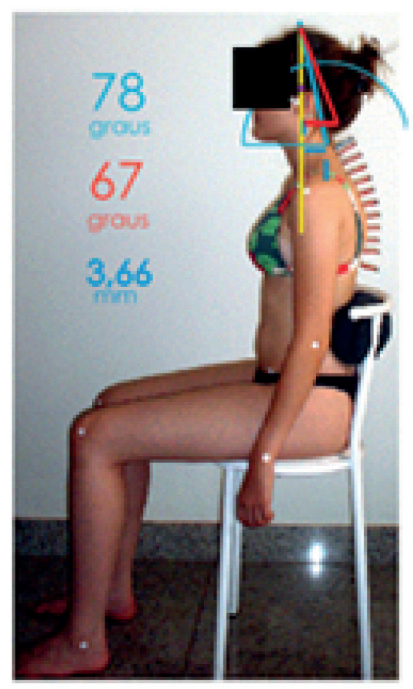

(B) com calço em L3

Figure 4 - Sitting positions: (A) in a chair with no backrest, angle of the head extensor muscles with the horizontal line $43^{\circ}$, angle of the reaction of the C7-T1 joint with the horizontal line $63^{\circ}, \mathrm{C} 7-\mathrm{y}$ axis distance $5.32 \mathrm{~mm}$; (B) with a $100^{\circ}$ tilted backrest, angle of the head extensor muscles with the horizontal line $60^{\circ}$, angle of the reaction of the C7-Tl joint with the horizontal line $72^{\circ}, \mathrm{C7}-\mathrm{y}$ axis distance $4.21 \mathrm{~mm}$; (C) with a $100^{\circ}$ tilted backrest and lumbar support cushion at $\mathrm{L} 3$, angle of the head extensor muscles with the horizontal line $67^{\circ}$, angle of the reaction of the C7-Tl joint with the horizontal line $78^{\circ}, \mathrm{C} 7-y$ axis distance $3.66 \mathrm{~mm}$.

The values obtained for muscle and joint reaction forces are shown in Table 1 . The values calculated for the flexion moment $\mathrm{M}_{(\mathrm{C} 7 \mathrm{~T} 1)}$ were $2.27 \mathrm{Nm}, 2.56 \mathrm{Nm}$ and $1.73 \mathrm{Nm}$ in positions $\mathrm{A}, \mathrm{B}$ and $\mathrm{C}$, respectively.

Table 1 - Force values obtained

\begin{tabular}{lcccc}
\hline & $\begin{array}{c}\text { FM angle with } \\
\text { horizontal line }\end{array}$ & $\begin{array}{c}\text { FJ angle with } \\
\text { horizontal line }\end{array}$ & Muscle Force & Joint Reaction Force \\
\hline \multicolumn{1}{c}{ POSTURES } & $\boldsymbol{\theta}[0]$ & $\boldsymbol{\beta}[0]$ & FM [N] & FJ[N] \\
\hline $\begin{array}{l}\text { A - With no } \\
\text { backrest }\end{array}$ & 43 & 63 & 52.1 & 83.9 \\
$\begin{array}{l}\text { B - With backrest } \\
\begin{array}{l}\text { C- Backrest + } \\
\quad \text { Lumbar support }\end{array}\end{array}$ & 60 & 72 & 58.3 & 94.4 \\
\end{tabular}




\section{Discussion}

The present study demonstrated the relationship between the position of vertebra L3 and the head when sitting. The results indicated an increase in forward head posture and neck muscle strain in the presence of a posterior tilt of vertebra L3, characterized by a reduction or even reversal of lordosis.

Head and neck pain is frequently associated with incorrect sitting posture. The sitting position is generally influenced by several factors, including the design of the chair, its ergonomic adaptation to the individual and the task to be performed. When sitting without a backrest, the pelvis tilts backwards and lumbar curvature is reduced or reversed, converting lordosis into kyphosis. Pressure on the intervertebral disc in this position (no backrest), measured at the level of L3, was $40 \%$ greater than that recorded with the subject standing (2). In the erect sitting position, the forward tilt of the pelvis preserves the concavity of lordosis, promoting a reduction in the load on this vertebral segment (21). However, this erect posture without a backrest puts excess strain on the muscles, making it unsuitable for performing tasks over prolonged periods. As such, the chair should allow for postural adjustments in order to reduce pressure on the intervertebral disc.

Nordin and Frankel (21) studied the influence of sitting position in a chair with a $90^{\circ}$ and $110^{\circ}$ tilted backrest, with and without lumbar support. The authors found that sitting with a $110^{\circ}$ tilted backrest reduces compression in the spinal discs when compared to the $90^{\circ}$ backrest. Moreover, the authors concluded that combining lumbar support with the tilted backrest further reduces intradiscal pressure. In the present study, use of a tilted backrest and lumbar support cushion favored the physiological curvature of the vertebra, in addition to reducing forward head posture.

Carneiro et al. (29) studied the erector spinae in different sitting positions. A comfortable sitting posture with the pelvis in a neutral position and a relaxed thoracic column showed a significant increase in flexion and forward head posture, in addition to a significant rise in the electrical activity of extensor muscles in the neck and thoracic column at $\mathrm{T} 4$. These findings were corroborated by the present study, where a relaxed sitting position resulted in greater neck extensor muscle force while upright posture exhibited lower neck muscle force and a smaller flexion moment. By contrast, Nordin and Frankel (21) found low electrical activity in all the positions despite the increased load in the different head positions. This suggests that the flexion moment is balanced by passive connective tissue structures such as capsules and ligaments.

Thus, studies show that the load on the neck is related to the trunk and the position of the head. The load moment is balanced by muscle force and the traction of passive connective tissue. The moment arm and corresponding muscle force are $50 \%$ higher at a forward head angle of $30^{\circ}$ when compared to values obtained with zero tilt (2). Load on the C7-T1 segment is 3 to 4 times greater with full head flexion. Vassavada et al. (30) evaluated the three-dimensional moment arm during maximal voluntary contraction of the neck muscles in humans. The authors calculated the maximum moment arm, generated under strain, at different points along the cervical spine of men and women. Magnitudes quantified were those related to the moment arms for extension, flexion, lateral tilt and axial rotation of the head. They concluded that the maximum extension moment of the head in men was $52 \pm 11 \mathrm{Nm}$ and $21 \pm 12 \mathrm{Nm}$ in women, and that the magnitude of the flexion moment decreased linearly with the vertical distance of the lower cervical spine toward the mastoid process. According to the authors, it is unclear how the size, sex and geometry of individuals affects the ability of neck muscles to generate momentum. Additionally, the authors measured the forward head angle in relation to C7-tragus and the Frankfort plane in 11 men and women considered to have good posture. The forward head posture (C7-tragus) measured for men and women was $50 \pm 4$ degrees, with a mean Frankfort plane of $8 \pm 5$ degrees for both sexes. These data corroborate the findings of the present study, where forward head posture in a sitting position using a backrest and combined with lumbar support was $50^{\circ}$ and $52^{\circ}$, respectively. The Frankfort plane measurement for both postures was $9^{\circ}$.

Nordin and Frankel (21) reported that the head flexion moments generated around the C7-T1 segment for static posture at slight and maximum flexion were $3.7 \mathrm{Nm}(3.0-6.2)$ and 4.3Nm (3.7-6.5), respectively. In a neutral neck position with the head straight, the flexion moment was $0.9 \mathrm{Nm}$, indicating a substantial increase in the load on C7-T1 as the head moved toward the front of the neck. The authors did not specify the angles measured for what 
they referred to as slight and maximum flexion. In the present study, flexion moments of $2.27 \mathrm{Nm}, 2.56 \mathrm{Nm}$ and $1.73 \mathrm{Nm}$ were obtained for head angles of $43^{\circ}$, $60^{\circ}$ and $67^{\circ}$, respectively; where $43^{\circ}$ represented the posture with the greatest head flexion. For extensor muscle force, a value of $52.1 \mathrm{~N}$ was recorded for an angle of $43^{\circ}$ in the sitting position without a backrest. In research by Ozkaya \& Nordin (31), head extensor muscle force of $50 \mathrm{~N}$ was observed for an angle of $30^{\circ}$.

The Tr-L3 horizontal distance in this study was directly related to forward head posture. The largest head inclination was measured in a sitting position with no backrest for a Tr-L3 horizontal distance of $18.88 \mathrm{~cm}$, while the smallest forward inclination was observed for a Tr-L3 distance of $10.23 \mathrm{~cm}$ when the subject was seated with a backrest and lumbar support cushion. There was a $46 \%$ decrease in the Tr-L3 horizontal distance and $9^{\circ}$ decline in forward head posture when sitting with a $100^{\circ}$ tilted backrest combined with lumbar support when compared to sitting without backrest.

Ruivo et al. (32) studied adolescents in a standing position with worrisome results, where $68 \%$ of participants exhibited forward head posture and $58 \%$ had rounded shoulders. Thus, biomechanical studies demonstrate the need for an extensive postural education project at the elementary school level. Moreover, the present study contributes to the development of ergonomic measures and increased awareness among employees whose work activities require them to sit. The use of chairs with a backrest, associated with a lumbar support cushion, proved to be an important additional preventive measure for the health of workers required to remain seated for prolonged periods.

\section{Conclusion}

A biomechanical study was conducted in three different sitting positions to compare the position of the head with lumbar curvature. The smallest exertion by neck extensors was observed in the posture with the shortest horizontal distance between the tragus and the L3 vertebra, where the lowest extensor muscle force, joint reaction force and flexion moment were obtained. As such, this study demonstrated the need to preserve the physiology of the lumbar axis, characterized by the position of the L3 vertebra, in order to ensure good head position when sitting. Additional studies using groups of individuals with different occupational activities are suggested in order to improve the quantification protocol of musculoskeletal exertion related to head and trunk posture.

\section{Acknowledgments}

The authors are grateful for the financial support provided by the National Council of Scientific and Technological Development (CNPq), Coordination for the Improvement of Higher Education Personnel (CAPES) and Research Support Foundation of the State of Minas Gerais (FAPEMIG).

\section{References}

1. Lennon J, Shealy NC, Cady RK, Matta W, Cox R, Simpson WF. Postural and respiratory modulation of autonomic function, pain, and health. Am J Pain Management. 1994;4(1):36-9.

2. Nordin M, Andersson GBJ, Pope MH. Musculoskeletal Disorders in the Workplace, principles and practice. St. Louis: Mosby; 1997.

3. McEvoy MP, Grimmer K. Reliability of upright posture measurements in primary school children. BMC Musculoskelet Disord. 2005;6(1):35-42.

4. Bricot B. Posturologia. 2nd ed. São Paulo: Ícone; 2001.

5. Marques NR, Hallal CZ, Gonçalves M. Características ergonômicas e clínicas da postura sentada: uma revisão. Fisioter Pesqui. 2010;17(3):270-6.

6. Nejati P, Lotfian S, Moezy A, Nejati M. The study of correlation between forward head posture and neck pain in Iranian office workers. Int J Occup Med Envir Health. 2015;28(2):295-303.

7. Yip CHT, Chiu TTW, Poon ATK. The relationship between head posture and severity and disability of patients with neck pain. Man Ther. 2008;13(2):148-54.

8. Fernandez-de-las-Peñas C, Alonso-Blanco C, Cuadrado ML, Pareja JA. Forward Head Posture and Neck Mobility in Chronic Tension-Type Headache. A Blinded, Controlled Study. Cephalalgia. 2006;26(3):314-9.

9. Svensson HF, Svensson OK. The influence of the viewing angle on neck-load during work with video display units. J Rehabil Med. 2001;33(3):133-6. 
10. Côté P, Velde G, Cassidy D, Carrol L, Hogg-Johnson S, Hom LW, et al. The Burden and Determinants of Neck Pain in Workers. Eur Spine J. 2008;17(Suppl 1):60-74.

11. Raine S, Twoey L. Posture of the head, shoulders and thoracic spine in comfortable erect standing. Aust J Physioter. 1994;40(1):25-32.

12. Alexopoulos EC, Stathi IC, Charizani F. Prevalence of musculoskeletal disorders in dentists. BMC Musculoskelet Disord. 2004;5:16.

13. Michalak-Turcotte C. Controlling dental hygiene work related musculoskeletal disorders: the ergonomic process. J Dent Hyg. 2000;74(1):41-8.

14. Gazzola F, Sartor N, Ávila SN. Prevalência de desordens musculoesqueléticas em odontologistas de Caxias do Sul. Ciência \& Saúde. 2008;1(2):50-6.

15. Kang JH, Park RY, Lee SJ, Kim JY, Yoon SR, Jung KI. The effect of the forward head posture on postural balance in long time computer based worker. Ann Rehabil Med. 2012;36(1):98-104.

16. Zandi S, Rajabi R, Alizadeh MH. Validity intratester and intertester reliability of a noninvasive quantitative forward posture assessment method. J Research Sport Rehabilitation. 2015;2(4):51-6.

17. Braum BL, Amundson LR. Quantitative assessment of head and shoulder posture. Arch Phys Med Rehabil. 1989;70(4):322-9.

18. Dalton MB. The effect of age on cervical posture in a normal female population. In: Jones HM, Jones MA, Milde MR, editors. Proceeding of the Sixth Biennial Conference of the Manipulative Therapists Association of Australia. Adelaide, 1989. p. 34-44.

19. Braum BL. Postural differences between asymptomatic men and women and craniofacial pain patients. Arch Phys Med Rehabil. 1991;72(9):653-6.

20. Watson DH, Trott PH. Cervical headache: an investigation of natural head posture and upper cervical flexor performance. Cephalagia. 1993;13(4):272-84.

21. Nordin M, Frankel V. Basic Biomechanics of the Musculoskeletal System. 2nd ed. Malvern (PA): Lea \& Febiger; 1989.

22. Harrison SS, Harrison SO, Croft AC, Harrison DE, Tryanovich SJ. Sitting biomechanics part l: review of literature. J Manipulative Physiol Ther. 1999;22(9):594-609.
23. Aroeira RMC, Leal JS, Pertence AEM. New Method of Scoliosis Assessment: Preliminary Results Using Computerized Photogrammetry. Spine. 2011;36(19):1584-91.

24. Ricieri DV. Biofotogrametria - Análise Cinemática Angular dos Movimentos. 2nd ed. Curitiba (Brazil): Inspirar; 2005.

25. Shumway-Cook A, Woollacott MH. Motor control: theory and practical applications. 2nd ed. Maryland: Williams \& Wilkins; 2001.

26. Bjerin AA. Comparison between the Frankfort horizontal and sella turcica-nasion as reference planes in cephalometric analysis. Acta Odontol Scond. 1957;15(1):1-12.

27. Melo SIL, Santos SG. Antropometria em Biomecânica: Características, Princípios e Modelos Antropométricos. Rev Bras Cineantropom Desempenho Hum. 2000;2(1):97-105.

28. Rodacki ALFR. Análise dos fatores antropométricos em biomecânica [cited 2011 Dec 15]. Available from: http://tinyurl.com/jzygb55.

29. Carneiro JP, O`Sullivan P, Burnet A, Barach A, O’Neil D, Tveit 0 , et al.The influence of different sitting posture on head/neck posture and muscle activity. Man Ther. 2010;15(1):54-60.

30. Vassavada AN, Li S, Delp SL. Three-Dimensional Isometric Strength of Neck Muscles in Humans. Spine J. 2001;26(17):1904-9.

31. Ozkaya N, Nordin M. Fundamental of Biomechanics - equilibrium, motion and deformation. New York: Springer Science; 1998.

32. Ruivo RM, Pezarat-Correia P, Carita AI. Cervical and shoulder postural assessment of adolescents between 15 and 17 years old and Association with upper quadrant pain. Braz J Phys Ther. 2014;18(4):364-71.

Received in 10/07/2015

Recebido em $07 / 10 / 2015$

Approved in 08/18/2016

Aprovado em 18/08/2016 
